\title{
Kaynaştırma Uygulamalarının Başarısını Etkileyen Etmenler, Sorunlar ve Ailelerden Beklentilerin Öğretmen Görüşlerine Göre Analizi (Karma Yöntem Araştırması)
}

\author{
Gülsün ŞAHAN ${ }^{1}$, Mahir UĞURLU², Nihal ÖZDEMİ³ ve Ayşenur NAZİK ${ }^{4}$
}

Öz

$\mathrm{Bu}$ çalışmanın amacı kaynaştırma eğitimi yapan öğretmenlere göre kaynaştırma uygulamalarının başarısını etkileyen etmenleri ortaya koymak, ögretmen görüşlerine göre sorunları belirlemek, ailelerden beklentileri değerlendirmektir. Araştırmanın evrenini Bartın il merkezinde görev yapan kaynaştırma eğitimi veren öğretmenler oluşturmaktadır. Örneklem grubunda en fazla kaynaştırma öğrencisi olan 7 okulda görev yapan öğretmenler yer almıştır. Bu çalışma kaynaştırma eğitimindeki problemleri daha iyi anlamak, tespit etmek amacıyla nicel ve nitel yaklaşımlar birlikte kullanılmıștır. Nicel veriler Ahmetoğlu, Ünal ve Ergin (2016) tarafından geliştirilen "Kaynaştırma Uygulamalarının Başarısını Etkileyen Etmenler Ölçeği” ile, nitel veriler araştırmacılar tarafından geliştirilmiş yarı yapılandırılmıș görüșme formları ile alınmıştır. Kaynaştırma eğitimi yapan 74 öğretmenden alınan veriler nicel olarak değerlendirmeye alınmıştır. Nitel değerlendirme için 29 öğretmenin görüşü incelenmiştir. Sonuç olarak öğretmen görüşleri arasında rehberlik araştırma merkezi ve aileler alt boyutlarında ve yaş gruplarına göre sivil toplum örgütleri alt boyutunda anlamlı farklılık olduğu bulunmuştur. Öğretmenlerin mesleki deneyimleri arasında rehber öğretmenler ve okul idarecileri boyutlarında anlamlı bir farklılık olduğu, branşlara göre anlamlı bir fark olmadığı görülmektedir. Öğretmenlerin ailelerden yeterli ve bilinçli düzeyde destek alamadıkları, eğitim süreci içerisinde kazandırılan becerilerin ev ortamında aile tarafından desteklenmediği ayrıca ailelerin okul ile iletşşimin çok az olduğu anlaşılmaktadır. Öğretmen beklentileri arasında velilerin okulla daha fazla ilişki kurması, veli toplantılarına katılmasının önemli olduğu, ailelerin çocukları ile daha fazla ilgilenmesi ayrıca okulda yapılan etkinliklerin evde daha fazla desteklenmesi gerektiği yer almaktadır.

Anabtar Kelimeler: Kaynaştırma eğitimi, Engelli bireyler, Kaynaştırma öğretmeni, Özel eğitim

\section{Analysis of Factors, Problems and Expectations from Families Affecting the Success of Inclusive Practices According to Teachers' Views (Mixed Method Research)}

\begin{abstract}
The aim of this study is to identify the factors affecting the success of inclusion practices according to the teachers engaged in inclusion education, to determine the problems according to the opinions of the teachers, to evaluate the expectations of families. The universe of research is composed of teachers who serve in the provincial center of Bartın, providing integration education. Teachers working in 7 schools with the highest inclusion students took part in the sample group. In this study, quantitative and qualitative approaches were used together in order to better understand and identify the problems in inclusion education. Quantitative data were obtained with the "Factors Affecting the Success of Integration Practices Scale" developed by Ahmetoğlu, Unnal, and Ergin (2016), and qualitative data were obtained with semi-structured interview forms developed by researchers. The data obtained from 74 teachers who teach inclusive education were evaluated quantitatively. For qualitative evaluation, 29 teachers opinions were examined. As a result, there was significant statistical difference among the guidance research centre, parents and ages group in terms of the non-governmental organizations sub-dimension. Based on findings, there was significant statistical difference among school counselor and school administrators in terms of the professional experiences of teachers in the subdimensions, but not according to the branches. The result of this study is to reveal that teachers do not receive sufficient and conscious support from families, the skills acquired during the education process are not supported by the family in the home environment, and there is little communication between families and the school. Among the expectations of teachers, it is stated that it is important for parents to establish more relations with the school, to attend parent meetings, that families should be more interested in their children and that activities at school should be supported more at home.
\end{abstract}

Key Words: Inclusive education, Disabled individuals, Mainstream teacher, Special education

\section{Atıf İçin / Please Cite As:}

Şahan, G., Uğurlu, M., Özdemir, M ve Naz, A. (2021). Kaynaştırma uygulamalarının başarısını etkileyen etmenler, sorunlar ve ailelerden beklentilerin öğretmen görüşlerine göre analizi (Karma Yöntem Araştırması). Manas Sosyal Arastırmalar Dergisi, 10(1), 136-150.

Geliş Tarihi / Received Date: 08.09.2020

Kabul Tarihi / Accepted Date: 20.12.2020

\footnotetext{
${ }^{1}$ Doç. Dr.- Bartın Üniversitesi Eğitim Fakültesi, gsahan@bartin.edu.tr - (D ORCID: 0000-0002-1215-9727

2 Arş. Gör.- Bartın Üniversitesi Eğitim Fakültesi, mugurlu@bartin.edu.tr - (DD ORCID: 0000-0003-4005-4882

3 Öğr. Gör.- Bartın Üniversitesi Eğitim Fakültesi, nozdemir@bartin.edu.tr - (D ORCID: 0000-0003-4587-2729

4 Öğr. Gör.-Bartın Üniversitesi Meslek Yüksek Okulu, anazik@bartin.edu.tr - (D ORCID: 0000-0002-8030-6071
} 


\section{Giriş}

Bireyin kendi ihtiyaçlarını karşılaması ve toplumla etkileşim halinde olmasının yolu kişinin iyi bir eğitim almasıyla mümkündür. Çağdaş toplumlarda eğitimde firsat eşitliği ilkesine bağlı olarak, toplumdaki normal gelişim gösteren bireyler ile özel gereksinimi olan bireyleri ayırt etmeden herkesin eşit eğitim hakkı olduğu kabul edilmiştir. Bu nedenle bireysel farklılıkları göz önünde bulundurarak bütün çocuklara, ihtiyaçları doğrultusunda eşit şekilde eğitim verilmesi gerektiği vurgulanmaktadır (Şahbaz ve Kalay, 2010, s. 2). Özel gereksinimi olan birey, "çeşitli nedenlerle bireysel ve gelişim özellikleri ile eğitim yeterlilikleri açısından akranlarından beklenen düzeyde anlamlı farklılıklar gösteren birey" olarak tanımlanmışıtır (MEB, 2012, s. 1). Bu tanım kapsamında, özel gereksinimi olan bireylerin eğitimi söz konusu olduğunda okul öncesinden başlayarak eğitimlerine önem verilmesi gerektiğĭ, özel gereksinimli çocukların gelişimsel yetersizliklerinden dolayı normal gelişim gösteren çocuklara göre birçok beceriyi daha yavaş öğrendikleri, bu gibi nedenlerle daha yoğun ve sistemli eğitim almaları gerektiği söylenebilir (Işık, 2018, s. 21). Ayrıca, özel gereksinimi olan çocuklara okul öncesi, ilköğretim, ortaokul ve ortaöğretim döneminde verilen eğitimlerin, onların ileriki eğitim ve meslek yaşantılarını da önemli ölçüde etkilemekte olup özel gereksinimi olan çocuklara gerekli olan eğitim fırsatının verilmemesi, onların eğitim yaşantılarında giderilmesi zor durumlarla karşılaşmalarına neden olabilmektedir (Bozarslan Malkoç, 2010, s. 8).

Kaynaştırma uygulamaları yetersizliğe sahip olan bireylere farklı alanlardaki gelişimlerine önemli katkılar sağlamaktadır. Yetersizliği olan bireyler tipik gelișim gösteren akranlarıyla aynı ortamda daha fazla sosyal etkileşim kurmakta; dil, iletişim ve akademik beceriler için uygun rol modeller görme olanağı elde etmektedir. Kaynaştırma ortamları en az kısıtlayıcı ortamlar olduğundan topluma uyum becerileri açısından yetersizliğe sahip bireyler için ayrı eğitim ortamlarına göre daha uygundur. Ayrıca kaynaştırma eğitimi tipik gelişim gösteren akranlar için de olumlu katkılar sağlamaktadır (Loreman, Deppeler ve Harvey, 2005). Özel gereksinimi olan bireylerin, sosyalleşebilmesi ve toplum içerisinde bağımsız olarak yaşamlarını sürdürebilmesi için eğitim kademesinin her bir aşamasında eğitim desteği almaları gerekmektedir. Özel gereksinimi olan öğrenciler iki farklı şekilde eğitim almaktadırlar. Birincisi kaynaştırma eğitimi adı verilen, özel gereksinimi olan öğrencilerin genel sınıflarda normal gelişim gösteren akranlarıla birlikte branş ögretmenleri tarafindan verilen eğitimdir. İkincisi ise normal gelişim gösteren akranlardan ayrı bireylerin farkllıklarına göre hazırlanan programlarla özel eğitimciler tarafından uygulanan eğitimdir (MEB, 2012). Özel gereksinimi olan öğrencileri, eğitimde firsat eşitliği ilkesine bağlı olarak, okul öncesi dönemden başlayarak normal gelişim gösteren akranları ile birlikte genel eğitim sınıflarında kaynaştırma eğitimine dâhil edilmeleri gerekmektedir. Kaynaştırma eğitiminin başta özel gereksinimli bireye olmak üzere tipik gelişim gösteren çocuğa, çocukların ailelerine ve kaynaştırma öğretmeni açısından yararlı olduğunu belirtmişlerdir (Akman, Mercan Uzun ve Yazıc1, 2018, s. 108). Kaynaştırma eğitimi amacıyla normal akranları ile aynı sınıfa gelen öğrencilerin engel düzeyleri düşüktür, dersi sürdürebilecek iletişim özellikleri bulunmakta olup bu tip öğrenciler yaklaşık olarak on beş dakika yerlerinde sabit oturabilmektedirler (Vural, 2007; Yazıcıŏlu, 2018 Akt: Bulu ve Hotaman, 2020, s. 717). Kaynaşıırma eğitimi yapan öğrenci sınıfın ders akışını bozmayacağından hem öğrenciye yararı olacak, hem de diğer öğrenciler farklı bireylerle bir arada olmayı deneyimlemiş olacaklardır. Kaynaştırma eğitiminin başarıya ulaşabilmesi için özel gereksinimli öğrencilerin eğitim hizmetlerinden en üst düzeyde faydalanabilmesi gerekmektedir. Bu öğrencilerin eğitimlerinin başarıya ulaşmasında etki eden çevre, fiziksel ortam, araç gereç gibi birçok etmen önemli olmakla birlikte eğitim veren öğretmenlerin ve ebeveynlerinin rolü oldukça önemlidir. Öğretmenin kaynaştırma eğitimi ve özel eğitime gereksinimi olan öğrenciye ilişkin olumlu ya da olumsuz görüşleri kaynaştırma eğitimini etkileyen en önemli unsurlardan biri iken (Işık, 2018, s. 21), başarılı bir kaynaştırma için önemli faktörlerden birinin öğretmenlerin kaynaştırmaya ilişkin istekli ve kabul edici olması vurgulanmakta olup sınıfinda kaynaştırma öğrencisi olan öğretmenlerinin başarılı bir kaynaştırma ortamı yaratması için bazı özelliklere sahip olması başarılı bir kaynaştırma için; kaynaştırma öğrencisi için öğretmenlerin değerlendirme ve program geliştirme çalışmalarına dahil olması, özel gereksinimi olan çocuğun bireysel farkl11ıkları göz önünde bulundurarak öğretim ortamı için öneriler geliştirebilmesi, ebeveynlere yol gösterebilmesi ve gerekli durumlarda onlarla etkileşime geçebilmesi ve sinıf içerisinde tüm çocuklara eşit imkanlar sunabilmesi gerekmektedir. Batu (2000, s. 40). Milli Eğitim Bakanı 2020 yllı bütçe sunuşunda devlet okullarında kaynaştırma eğitimi gören engelli öğrenci sayısı 2019 yılı itibarıly 295 bin 697 olduğunu belirtmiştir. Ayrıca tam zamanlı kaynaştırma/bütünleştirme yoluyla eğitim uygulamaları kapsamında eğitimlerini sürdüren öğrenciler için eğitim kurumlarında destek eğitim odaları olduğu ve bu ögrencilerin eğitim hizmetlerinden maksimum seviyede yararlanmaları temel amaçlardan biri olduğunu vurgulamaktadır. Bu kapsamda 12.807 destek eğitim odası ile kaynaştırma/bütünleştirme yoluyla 
eğitimlerini sürdüren öğrencilere destek eğitim hizmeti verilmektedir. 2018-2019 eğitim ve öğretim yllında destek eğitim odalarında 44.206 öğrenciye 73.027 öğretmen ile destek eğitim hizmeti verilmiştir (Ayvaz Öztürk, 2020, s. 73).

Kaynaştırma eğitimi ile ilgili araştırmalar incelendiğinde personel eğitimi ve personel tutumuna yönelik çalışmaların ilk sıralarda yer alması, kaynaştırma eğitimi uygulamalarının istenilen düzeyde olmadı̆̆1 dikkate alındığında beklenen bir durumdur (Gün Şahin ve Gürbüz, 2016, s. 142; Sucuoğlu ve Akalın, 2010, s. 19; Aküzüm ve Altunhan, 2017, s. 780; Nazıf Toy ve Duru, 2016, s. 47). Mevcut eğitimciler üzerinde yapılan araştırmaların yanı sıra, geleceğin öğretmenleri olan çeşitli branşlardaki öğretmen adaylarının eğitimlerine ve tutumlarına yönelik araştırmalar olduğu da görülmektedir (Öztürk, Ballığlu ve Şen; 2014, s. 2). Sanır'ın (2009) bir çalışmasına göre öğretmenlerin kaynaştırma öğrencilerinin özellikleriyle ilgili yeterli bilgileri bulunmadığı, bu öğrencileri isteyerek almadıkları, bu çocuklarla eğitim yapmanın zor olduğu, kaynaştırma öğrencilerinin akranlarına göre geride oldukları, bu konuda eğitim almadıkları ve branşlarının özel eğitim olmadığı, öğrencilerin akademik başarısızlıklarının engellerinden kaynaklı olduğunu düşündükleri ayrıca ailelerin de çocuklarının engel türleri ve kaynaştırma eğitimi konusunda yeterli bilgiye sahip olmadıkları, çocuklarının normal okullarında eğitim görmesini istedikleri anlaşılmıştır. Kaynaştırma eğitiminin başarısında ailede oldukça önemlidir. Kaynaştırma eğitimi alan öğrencileri her yönüyle tanıyan aileler çocuklarının okul içi ve okul dışı eğitimlerinde önemli bir rol üstlenirler (Berkant ve Atılgan, 2017). Kaynaştırma uygulamalarının başarısı kaynaştırma için gerekli desteklerin sağlanması ile mümkün olabilmektedir. Kaynaştırma desteğinin sağlanması için başlıca modeller arasında öğretmenlere hizmet içi eğitimler verilmesi, öğretmen yardımcilarından destek alınması, gezici öğretmenlik uygulaması yer almaktadır. Kaynaştırma eğitimi alan öğrenciler devam ettikleri sınıfın müfredatını ve eğitim programını izlerler. Bununla birlikte kaynaştırma öğrencileri için yetersizlik türü ve düzeyleri, özellikleri, performans düzeyleri, yeterliliklerine göre programlarda uyarlamalar ve düzenlemeler yapılır. Kaynaştırma uygulamaları programlarında müfredat uyarlamaları, ögretimsel uyarlamalar, materyal uyarlamaları, ortam uyarlamaları bulunmaktadır (Batu, 2008; Akçin, 2017). Kaynaştırma eğitimi ile ilgili yapılmış Berkant ve Atılgan'ın (2017) çalışmasında sınıf öğretmenlerinin kaynaştırma eğitimi ile ilgili yaşamış oldukları sorunların ve bu sorunlara yönelik çözüm önerilerinin belirlenmesine çalışlımıştır. Türkiye' de kaynaştırma uygulamalarından istenilen faydanın sağlanabilmesi için birtakım düzenleme ve değişikliklere ihtiyaç vardır, bu nedenle kaynaştırma uygulamalarının yapıldığı okullarda kaynaştırma uygulamasının başarısını etkileyen etmenlerin anlaşılması için var olan durumun saptanması gerekmektedir (Ahmetoğlu, Ünal, Ergin, 2016). Öğretmenlerin kaynaştırma eğitimine yönelik bakış açılarının neler olduğu incelendiğinde, elde edilen sonuçların kaynaştırmaya yönelik başarının eğitimcilerden kaynaklandığı ve eğitimcilerin kaynaştırmaya yönelik olumlu görüş bildirdikleri (Sart, Ala, Yazlık ve Yılmaz, 2004; Orel, Zerey ve Töret 2004; Şekercioğlu, 2010) olumlu görüşler belirtilmesine rağmen, aksi görüşlerin de olduğu belirlenmiştir (Sadioğlu, Bilgin, Batu ve Oksal, 2013; Uysal, 2004). Ancak başarlı bir kaynaştırma uygulamasının tek öğesi eğitimciler değildir. Normal gelişim gösteren öğrenciler, okul yöneticileri, aileler, eğitim ortamları ve özel eğitim destek hizmetleri de bir bütün olarak etkilidir (Batu ve Kurcaali-İftar, 2009). Konu ile ilgili yapılmış çalışmalar bulunmasına rağmen kaynaştırma eğitiminde yaşanan sıkıntıların devam ettiği, bu nedenle bu konuda daha fazla çalışma yapılmasına ihtiyaç bulunduğu söylenebilir. Kısacası kaynaştırma eğitiminin başarılı olması için öğretmen görüşlerine göre sorun ve çözüm önerilerinin saptanması, bu eksikliklerin giderilmesi ve doğru uygulamaların yapılması önemlidir. Kaynaştırma uygulamalarının başarılı olmasında normal gelişim gösteren öğrenciler ile özel gereksinimi olan öğrencilerin birbirine uyum sağlamaları gerekmektedir. Bu çalışmanın ilgili literatüre katk1 yapacağı düşünülmektedir.

Bu çalışmanın amacı kaynaştırma eğitimi yapan öğretmenlere göre kaynaştırma eğitiminin başarısını ortaya koymak, sorun ve çözüm önerilerini değerlendirmektir. Bu amaca ulaşmak için aşağıdaki sorulara cevap aranmıştır.

1. Öğretmenlerin kaynaştırma uygulamalarının başarısını etkileyen etmenlere ilişkin görüşleri arasında cinsiyete göre fark var midır?

2. Öğretmenlerin kaynaştırma uygulamalarının başarısını etkileyen etmenlere ilişkin görüşleri arasında yaş gruplarına göre fark var midır?

3. Öğretmenlerin kaynaştırma uygulamalarının başarısını etkileyen etmenlere ilişkin görüşleri arasında mesleki deneyime göre fark var mıdır?

4. Öğretmenlerin kaynaştırma uygulamalarının başarısını etkileyen etmenlere ilişkin görüşleri arasında branşlara göre fark var mıdır?

5. Öğretmenlere göre kaynaştırma eğitiminde karşılaşılan sorunlar nelerdir? 


\section{6. Öğretmenlerin ailelerden beklediği destekler nelerdir?}

\section{Yöntem}

$\mathrm{Bu}$ araştırmada sorunların daha iyi anlaşılması amacıyla nicel ve nitel yöntemler bir arada kullanılmışır. Karma yöntemlerde bir yöntemden elde edilen bulguların detaylandırılması, sunulması, artırılması ve açıklığa kavuşturulmasın aşamasında diğer yöntemin sonuçlarını kullanma Tamamlayıcı Karma Yöntem olarak açıklanmaktadır, amaç hem de olayı farklı açılardan ölçmek hem de ayrıntılı hale getirmek için kullanılmış olup her bir veri analizi türü bir diğerini tamamlamıştır. Farklı yöntemler kullanmadaki amaç bulguların tutarlılı̆ını sağlamak değildir (Greene vd. 1989, Giannakaki, 2005 Akt: Baki ve Gökçek, 2012, s. 4). Nicel araştırmada tarama deseni kullanılmıştır. Tarama araştırmaları bir konu ya da olaylara ilişkin araştırmaya katılanların ilgi, beceri, düşünce, yetenek, tutum, düşünce gibi özelliklerini belirlemek için evrenden seçilen örneklem gruba ilişkin bilgilerin toplandığı araştırmalardır (Karasar, 2011). Bu çalşsmanın nicel analizleri SPSS programları ile analiz edilmiş, $t$ testi, ANOVA ve post hoc (LSD Testi) testleri yapılmıstır. Araştırmanın evrenini Bartın il merkezinde görev yapan kaynaştırma eğitimi veren öğretmenler oluşturmaktadır. Örneklem grubunda 74, çalışma grubunda 29 öğretmen bulunmaktadır. Örneklem seçiminde Rehberlik Araştırma Merkezinden talep edilen istatistiksel veriler doğrultusunda tam zamanlı kaynaştırma eğitimi alan öğrencilerin sayısının fazla olduğu 7 okulda görev yapan öğretmenler araştırma kapsamına alınmıştır.

\section{Çalışma Grubu}

Çalışma grubunda 46 kadın, 28 erkek öğretmen bulunmaktadır. Bunlardan 42 kişi 30-39 yaş, 20 kişi 20-29 yaş, 9 kişi 40-49 yaş, 3 kişi 50-59 yaş aralığındadır. 30 kişi 6-10 yll, 22 kişi 1-5 yll, 10 kişi 11-15, 6 kişi 16-20 yıl, 6 kişi 20 yıl üzerinde mesleki deneyime sahiptir. Branşlarını ise 12 kişi belirtmemiş, 9 kişi sınıf öğretmeni, 12 kişi matematik, 7 kişi Türkçe, 6 kişi İngilizce, 6 kişi edebiyat, 6 kişi fen bilimleri, 4 kişi özel eğitim, 3 kişi bilişim, 3 kişi sosyal bilgiler, 3 kişi çocuk gelişimi branşındadır. Ayrıca öğretmenlerin tamamının görüşleri formlar yardımı ile yazılı olarak alınmıştır. İncelenmeye uygun bulunan 29 öğretmen görüşü değerlendirilmiştir. Bu araştırma Bartın Üniversitesi Etik Kurulu’ndan ve İl Milli Eğitim Müdürlügü’nden gerekli izinler alınarak gerçekleştirilmiştir.

\section{Veri Toplama Araçları}

Bu çalısma nicel ve nitel araştırma yöntemlerinin bir arada kullanıldığı karma yöntem araştırması olup, veriler Ahmetoğlu, Ünal ve Ergin (2016) tarafindan geliştirilen "Kaynaştırma Uygulamalarının Başarısını Etkileyen Etmenler Ölçeği” ile öğretmenlerden alınmıştır. Ölçekte 66 madde ve 10 faktör bulunmakta olup alınan puanın yüksek oluşu sorun düzeyinin yüksek olduğunu göstermektedir. Ayrıca 3 özel eğitim alan uzmanı olan araştırmacılar tarafindan hazırlanan yarı yapılandırılmış görüşme formları hazırlanmış, özel eğitim ve eğitim yönetimi alanında görev yapan iki uzman görüşü ile son şekli verilmiş olup, kaynaştırma uygulamalarında karşılaşılan sorunlar ve ailelerden beklentilere ilişkin öğretmen görüşleri yazılı olarak alınmıştır. Alınan yazılı görüşler doküman incelemesine uygun olarak içerik analizi ile değerlendirilmiştir. Öğretmenlerin tamamına "Kaynaştırma Uygulamalarının Başarısını Etkileyen Etmenler Ölçeği” uygulanmış, ölçeği uygun şekilde cevaplayan 74 kişinin görüşünden elde edilen veriler SPSS programı ile analiz edilmiştir.

Kaynaştırma Uygulamalarmın Başarısın Etkileyen Etmenler Ölçeği. Ölçek 5'li likert şeklinde 66 sorudan oluşmaktadır. Ölçeğin geliştirilmesi istatistiklerine ilişkin olarak alt boyutlanı belirlemek için Açımlayıcı Faktör Analizi (AFA) kullanılmışıı. Her bir alt boyut için ayrı ayrı madde toplam korelasyon katsayısı ve madde hariç toplam korelasyon katsayısı hesaplanmış ve madde geçerlik sonuçları elde edilmiştir. Benzer biçimde maddelerin ayırt etme gücünü belirleyebilmek için üst çeyrek ve alt çeyrekler arasında t-testi uygulanmış ve sonucunda ayırt etme güçleri yüksek olarak bulunmuştur. Ölçek ve alt boyutlar için Cronbach Alfa ve Rulon katsayılarının hesaplanmasıyla güvenirlik belirlenmiştir. Yapılan istatistiksel işlemler sonucunda 10 alt boyuttan oluşan ölçek geçerli, güvenilir ve kullanılabilirdir. Tüm faktörlerden her biri için ayrı ayrı olarak iç tutarlık güvenirliği belirlemek amaciyla madde toplam korelasyon ve madde hariç toplam korelasyon, Rulon (0.960 ile 0.707 arasinda), Cronbach Alfa (0.947 ile 0.707 arasinda) katsayiları belirlenmiştir. $\mathrm{Bu}$ analizlere göre tüm maddelerin faktör analiziyle belirlenen faktörleriyle iç tutarlık gösterdiği görülmüştür (Ahmetoğlu vd., 2016). 


\section{Verilerin Analizi}

Araştırmanın nicel verilerin form kontrolleri yapılıp uygun olmayan formlar değerlendirilme dışında tutulmuştur. Daha sonra kodlama hataları giderilerek uç değerler belirlenmiş ve veriler SPSS 23 paket programı ile analiz edilmiştir. Verilerin normal dağılıp dağılmadığını öğrenmek için Kolmogorov Smirnov ve Shapiro Wilk testleri yapılmıştır ve verilerin normal dağıldığı belirlenmiştir. Araştırmada öğretmenlerin cinsiyetine, yaş gruplarına, mesleki deneyimlerine ve branşlarına göre ölçek alt boyutlarından alınan toplam puanların ve aralarında anlamlı farklılık olup olmadığının belirlenmesi için bağımsız örneklemler için $\mathrm{t}$ Testi ve bağımsız örneklemler için Tek Yönlü ANOVA testinden yararlanılmıştır.

\section{Bulgular}

Bu bölümde öğretmenlerin kaynaştırma uygulamalarının başarısını etkileyen etmenler ve karşılaşılan sorunlara ilişkin görüşleri değerlendirilmiş, analiz sonuçları bu bölümde yer almıştır.

\section{Öğretmenlere göre kaynaştırma uygulamalarının başarısını etkileyen etmenlere ilişkin bulgular}

Öğretmenlerin kaynaştırma uygulamalarının başarısını etkileyen etmenler ölçeğine verdikleri cevaplar analiz edilmiş, test sonuçları aşağıda yer almıştır. Öğretmenlerin cinsiyetine göre $t$ testi sonuçları Tablo 1'de görülmektedir.

Tablo 1. Ögrretmenlerin Cinsiyetine Göre Ölçek Alt Boyutlar Puanlarna İlişkin t Testi Sonuclar

\begin{tabular}{|c|c|c|c|c|c|c|c|c|}
\hline Alt Boyutlar & Cinsiyet & $\mathbf{N}$ & Ortalama & $\begin{array}{c}\text { Standart } \\
\text { Sapma }\end{array}$ & sd & $\mathbf{t}$ & $\mathrm{p}$ & d \\
\hline \multirow{2}{*}{ Sınıf Öğretmenleri } & Kadın & 46 & 47,50 & 2,952 & \multirow[t]{2}{*}{72} & \multirow[t]{2}{*}{1,171} & \multirow[t]{2}{*}{.991} & \multirow[t]{2}{*}{.04} \\
\hline & Erkek & 28 & 47,64 & 3,059 & & & & \\
\hline Rehber & Kadın & 46 & 16,12 & 1,576 & \multirow{2}{*}{72} & \multirow{2}{*}{1,099} & \multirow[t]{2}{*}{.446} & \multirow{2}{*}{.72} \\
\hline Öğretmenler & Erkek & 28 & 17,31 & 1,688 & & & & \\
\hline \multirow{2}{*}{ Uygulama } & Kadin & 46 & 29,55 & 1,604 & \multirow[t]{2}{*}{72} & \multirow[t]{2}{*}{1,630} & \multirow[t]{2}{*}{.085} & \multirow[t]{2}{*}{.87} \\
\hline & Erkek & 28 & 31,00 & 1,696 & & & & \\
\hline Mevzuat ve & Kadın & 46 & 27,00 & 1,513 & \multirow[t]{2}{*}{72} & \multirow[t]{2}{*}{1,183} & \multirow[t]{2}{*}{.079} & \multirow[t]{2}{*}{.41} \\
\hline Yönetmelikler & Erkek & 28 & 27,65 & 1,609 & & & & \\
\hline Sivil Toplum & Kadın & 46 & 20,51 & 1,216 & \multirow[t]{2}{*}{72} & \multirow[t]{2}{*}{,- 596} & \multirow[t]{2}{*}{.531} & \multirow[t]{2}{*}{.41} \\
\hline Örgütleri & Erkek & 28 & 21,01 & 1,272 & & & & \\
\hline Rehberlik Araştırma & Kadın & 46 & 12,05 &, 866 & \multirow[t]{2}{*}{72} & \multirow[t]{2}{*}{1,781} & \multirow[t]{2}{*}{$.018^{*}$} & \multirow[t]{2}{*}{35} \\
\hline Merkezi & Erkek & 28 & 12,35 & ,871 & & & & \\
\hline \multirow{2}{*}{ Okul İdarecileri } & Kadin & 46 & 12,50 & ,988 & \multirow[t]{2}{*}{72} & \multirow[t]{2}{*}{1,470} & \multirow[t]{2}{*}{.109} & \multirow[t]{2}{*}{.59} \\
\hline & Erkek & 28 & 13,08 & ,989 & & & & \\
\hline \multirow{2}{*}{ Aileler } & Kadin & 46 & 14,41 &, 817 & \multirow[t]{2}{*}{72} & \multirow[t]{2}{*}{1,995} & $.034 *$ & .93 \\
\hline & Erkek & 28 & 15,18 &, 844 & & & & \\
\hline Fiziki Kosullar & Kadın & 46 & 6,84 & ,453 & 72 & 1,439 & .594 & .43 \\
\hline F1zık1 Koşullar & Erkek & 28 & 7,04 & ,481 & & & & \\
\hline Normal Gelişen & Kadin & 46 & 7,80 & ,444 & 72 &,- 346 & .736 & .22 \\
\hline Öğrenciler & Erkek & 28 & 7,90 & ,454 & & & & \\
\hline
\end{tabular}

$* \mathrm{p}<, 05$

Tablo 1'deki analiz sonuçları incelendiğinde anlamlı farklılık olan ölçek alt boyutlarının öğretmenlerin cinsiyetlerine göre fark olduğu ortalama puanları incelendiğinde ise rehberlik araştırma merkezi alt boyutuna ilişkin cinsiyete göre fark olduğu, ortalama puanlar erkek $(12,35)>$ kadın $(12,05)$; aileler alt boyutuna ilişkin cinsiyete göre o fark olduğu, ortalama puanlar erkek $(15,18)>$ kadın $(14,41)$ olduğu görülmektedir. Yaş gruplarına göre yapılmıs ANOVA testi Tablo 2'de yer almaktadır. 
Tablo 2. Yaş Gruplarna Göre Ögrretmenlerin Ölçek Alt Boyutlar Puanlarna İlişkin ANOVA Testi Sonuçlar

\begin{tabular}{|c|c|c|c|c|c|c|c|}
\hline Alt Boyutlar & Varyans Kaynağı & $\begin{array}{c}\text { Kareler } \\
\text { Toplamı }\end{array}$ & sd & $\begin{array}{c}\text { Kareler } \\
\text { Ortalamas1 }\end{array}$ & $\mathbf{F}$ & $\mathrm{p}$ & $\eta^{2}$ \\
\hline \multirow{4}{*}{ Sınıf Öğretmenleri } & Gruplar Arası & 73.043 & 3 & 24.348 & .157 & .925 & .001 \\
\hline & Gruplar İçi & 10850.106 & 70 & 155.002 & & & \\
\hline & Toplam & 10923.149 & 73 & & & & \\
\hline & Gruplar Aras1 & 144.096 & 3 & 48.032 & 1,132 & .342 & .046 \\
\hline \multirow[t]{3}{*}{ Rehber Öğretmenler } & Gruplar İçi & 2969.756 & 70 & 42.425 & & & \\
\hline & Toplam & 3113.851 & 73 & & & & \\
\hline & Gruplar Aras1 & 33.023 & 3 & 11.008 & .233 & .873 & .010 \\
\hline \multirow[t]{2}{*}{ Uygulama } & Gruplar İçi & 3309.260 & 70 & 47.275 & & & \\
\hline & Toplam & 3342.284 & 73 & & & & \\
\hline \multirow{3}{*}{$\begin{array}{l}\text { Mevzuat ve } \\
\text { Yönetmelikler }\end{array}$} & Gruplar Aras1 & 13.700 & 3 & 4.567 & .110 & 954 & .005 \\
\hline & Gruplar İçi & 2911.165 & 70 & 41.588 & & & \\
\hline & Toplam & 2924.865 & 73 & & & & \\
\hline \multirow{3}{*}{ Sivil Toplum Örgütleri } & Gruplar Arası & 167.401 & 3 & 55.800 & 2,304 & $.034 *$ & . 090 \\
\hline & Gruplar İçi & 1695.086 & 70 & 24.216 & & & \\
\hline & Toplam & 1862.486 & 73 & & & & \\
\hline \multirow{3}{*}{$\begin{array}{l}\text { Rehberlik Araştırma } \\
\text { Merkezi }\end{array}$} & Gruplar Aras1 & 19.750 & 3 & 40,139 & .479 & .698 & .020 \\
\hline & Gruplar İçi & 961.115 & 70 & 9,540 & & & \\
\hline & Toplam & 980.865 & 73 & & & & \\
\hline \multirow{3}{*}{ Okul İdarecileri } & Gruplar Aras1 & 84.603 & 3 & 28.201 & 1,680 & .179 & .067 \\
\hline & Gruplar İçi & 1174.910 & 70 & 16.784 & & & \\
\hline & Toplam & 1259.514 & 73 & & & & \\
\hline \multirow{3}{*}{ Aileler } & Gruplar Aras1 & 20.528 & 3 & 6.843 & .556 & 646 & .023 \\
\hline & Gruplar İçi & 861.310 & 70 & 12.304 & & & \\
\hline & Toplam & 881.838 & 73 & & & & \\
\hline \multirow{3}{*}{ Fiziki Koşullar } & Gruplar Aras1 & 8.128 & 3 & 2.709 & .759 & .521 & .031 \\
\hline & Gruplar İçi & 249.926 & 70 & 3.570 & & & \\
\hline & Toplam & 258.054 & 73 & & & & \\
\hline \multirow{3}{*}{$\begin{array}{l}\text { Normal Gelişen } \\
\text { Çocuklar }\end{array}$} & Gruplar Arası & 10.493 & 3 & 3.498 & 1,031 & .384 & .042 \\
\hline & Gruplar İçi & 237.467 & 70 & 3.392 & & & \\
\hline & Toplam & 247.959 & 73 & & & & \\
\hline
\end{tabular}

$* \mathrm{p}<, 05$

Tablo 2'deki analiz sonuçları incelendiğinde ANOVA testi sonucunda anlamlı farklılık olan alt boyutlarda farkın hangi gruplar arasında olduğunu tespit etmek amacıyla çoklu karşılaştırmalar yapmak üzere Post Hoc tekniklerinden LSD Testi yapılmıştır. Test sonucunda ulaşılan analiz sonuçlarına Tablo 3’te yer verilmiştir.

Tablo 3. Yaş Gruplarna Göre Öğretmenlerin Ölçek Puanlar İçin Uygulanan ANOV A Testi Sonucu Anlamlı Farklilık Olan Ölçek Alt Boyutlar Puanlarna İlişkin Cokelu Karşılaştırma Post Hoc (LSD Testi) Sonuclar

\begin{tabular}{ccl}
\hline & Post Hoc (LSD) & \\
Alt Boyutlar & Grup Karş1laştırmaları & p \\
\hline \multirow{2}{*}{ Sivil Toplum Örgütleri } & $20-29$ Yaş $-30-39$ Yaş & .332 \\
& $20-29$ Yaş $-40-49$ Yaş & .638 \\
& $20-29$ Yaş $-50-59$ Yaş &, $023^{*}$ \\
& $30-39$ Yaş $-40-49$ Yaş & .220 \\
& $30-39$ Yaş $-50-59$ Yaş & .054 \\
& $40-49$ Yaş $-50-59$ Yaş & $.017^{*}$ \\
\hline
\end{tabular}

$* \mathrm{p}<, 05$

Tablo 3'te yer alan analiz sonuçları incelendiğinde öğretmenlerin ölçek alt boyutlarından aldıkları puanlar ile yaş grupları arasında sadece sivil toplum örgütleri ölçek alt boyutunda anlamlı bir farklılık olduğu görülmektedir. Yapılan çoklu karşılaştırmalar sonucunda 20-29 Yaş - 50-59 Yaş (p=,023) ve 40-49 Yaş - 50-59 Yaş $(\mathrm{p}=, 017)$ arasında anlamlı farklılık olduğu bulunmuştur. Öğretmenlerin mesleki deneyimlerine göre ANOVA testi sonuçları Tablo 4'te yer almaktadır. 
ŞAHAN, UĞURLU, ÖZDEMİR ve NAZIKK

Kaynaştırma Uygulamalarının Başarısın Etkileyen Etmenler, Sorunlar ve Ailelerden Beklentilerin Öğretmen Görüşlerine Göre Analizi (Karma Yöntem Araştırması)

Tablo 4. Öğretmenlerin Mesleki Deneyimlerine Göre Ölçek Alt Boyutlar Puanlarna İlişkin ANOV A Testi Sonuçlar

\begin{tabular}{|c|c|c|c|c|c|c|c|}
\hline Alt Boyutlar & Varyans Kaynağı & $\begin{array}{c}\text { Kareler } \\
\text { Toplamı }\end{array}$ & sd & $\begin{array}{c}\text { Kareler } \\
\text { Ortalamas1 }\end{array}$ & $\mathbf{F}$ & $\mathrm{p}$ & $\eta^{2}$ \\
\hline \multirow{3}{*}{ Sınıf Öğretmenleri } & Gruplar Aras1 & 68.257 & 4 & 49.742 & .458 & .452 & .006 \\
\hline & Gruplar İçi & 11940.574 & 69 & 163.210 & & & \\
\hline & Toplam & 12008.831 & 73 & & & & \\
\hline \multirow{3}{*}{ Rehber Öğretmenler } & Gruplar Aras1 & 136.133 & 4 & 96.522 & 2,011 & $.028^{*}$ & .053 \\
\hline & Gruplar İçi & 2440.277 & 69 & 84.002 & & & \\
\hline & Toplam & 2576.410 & 73 & & & & \\
\hline \multirow{3}{*}{ Uygulama } & Gruplar Aras1 & 22.334 & 4 & 9.366 & .523 & .581 & .005 \\
\hline & Gruplar İçi & 4107.330 & 69 & 37.475 & & & \\
\hline & Toplam & 4129.664 & 73 & & & & \\
\hline \multirow{3}{*}{$\begin{array}{l}\text { Mevzuat ve } \\
\text { Yönetmelikler }\end{array}$} & Gruplar Aras1 & 11.880 & 4 & 12.856 & .239 & .774 & .005 \\
\hline & Gruplar İçi & 2544.334 & 69 & 34.112 & & & \\
\hline & Toplam & 2556.214 & 73 & & & & \\
\hline \multirow{3}{*}{ Sivil Toplum Örgütleri } & Gruplar Aras1 & 189.335 & 4 & 89.575 & 1,742 & .223 & .118 \\
\hline & Gruplar İçi & 1414.782 & 69 & 45.053 & & & \\
\hline & Toplam & 1604.117 & 73 & & & & \\
\hline \multirow{3}{*}{$\begin{array}{l}\text { Rehberlik Araştırma } \\
\text { Merkezi }\end{array}$} & Gruplar Arası & 13.540 & 4 & 40,139 & .165 & .439 & .016 \\
\hline & Gruplar İçi & 811.364 & 69 & 13,224 & & & \\
\hline & Toplam & 824.814 & 73 & & & & \\
\hline \multirow{3}{*}{ Okul İdarecileri } & Gruplar Aras1 & 62.255 & 4 & 14.305 & .887 & $.042^{*}$ & .058 \\
\hline & Gruplar İçi & 1013.874 & 69 & 19.145 & & & \\
\hline & Toplam & 1076.429 & 73 & & & & \\
\hline \multirow{3}{*}{ Aileler } & Gruplar Aras 1 & 44.956 & 4 & 13.552 & .420 & .988 & .065 \\
\hline & Gruplar İçi & 651.859 & 69 & 19.748 & & & \\
\hline & Toplam & 696.815 & 73 & & & & \\
\hline \multirow{3}{*}{ Fiziki Koşullar } & Gruplar Aras1 & 23.452 & 4 & 5.849 & .364 & .710 & .086 \\
\hline & Gruplar İçi & 249.926 & 69 & 4.223 & & & \\
\hline & Toplam & 273.378 & 73 & & & & \\
\hline \multirow{3}{*}{$\begin{array}{l}\text { Normal Gelişen } \\
\text { Çocuklar }\end{array}$} & Gruplar Aras1 & 8.333 & 4 & 7.986 & .689 & .505 & .023 \\
\hline & Gruplar İçi & 362.021 & 69 & 5.566 & & & \\
\hline & Toplam & 370.354 & 73 & & & & \\
\hline
\end{tabular}

Tablo 4'deki analiz sonuçları incelendiğinde ANOVA testi sonucunda anlamlı farklilık olan alt boyutlarda farkın hangi gruplar arasında olduğunu tespit etmek amacıyla çoklu karşılaştırmalar yapmak üzere Post Hoc tekniklerinden LSD Testi yapılmıştır. LSD test sonucunda ulaşılan analiz sonuçlarına Tablo 5'te yer verilmiştir.

Tablo 5. Mesleki Deneyimlerine Göre Öğretmenlerin Ölçek Puanlar İ̧in Uygulanan ANOVA Testi Sonucu Anlamlı

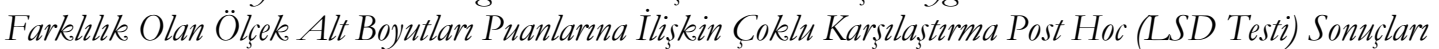

\begin{tabular}{|c|c|c|c|}
\hline \multirow{2}{*}{ Alt Boyutlar } & \multirow[b]{2}{*}{ Mesleki Deneyim } & \multicolumn{2}{|c|}{ Post Hoc (LSD) } \\
\hline & & Grup Karşılaştırmaları & $\mathrm{p}$ \\
\hline \multirow{10}{*}{ Rehber Öğretmenler } & \multirow{2}{*}{ 1-5 Yil } & 1-5 Yil - 6-10 Y 11 & .999 \\
\hline & & 1-5 Y1l - 11-15 Yil & .783 \\
\hline & \multirow{2}{*}{ 6-10 Yil } & 1-5 Yil - 16-20 Yll & .635 \\
\hline & & 1-5 Yil - 21 Yil Üstü & .204 \\
\hline & \multirow{2}{*}{$11-15 Y_{11}$} & $6-10 Y_{11}-11-15 Y_{11}$ & $.023^{*}$ \\
\hline & & $6-10 \mathrm{Y}_{11}-16-20 \mathrm{Y}_{11}$ & .999 \\
\hline & \multirow{2}{*}{ 16-20 Y1l } & 6-10 Yil - 21 Yil Üstü & .436 \\
\hline & & $11-15 Y_{1 l}-16-20 Y_{1 l}$ & $.011^{*}$ \\
\hline & \multirow{2}{*}{21 Yil Üstü } & 11-15 Yil - 21 Yil Üstü & .453 \\
\hline & & $16-20 Y_{11}-21$ Yil Üstü & .999 \\
\hline \multirow{10}{*}{ Okul İdarecileri } & \multirow{2}{*}{ 1-5 Y1l } & 1-5 Yil - 6-10 Yil & .226 \\
\hline & & 1-5 Yil - 11-15 Yil & .308 \\
\hline & \multirow{2}{*}{ 6-10 Yil } & $1-5 Y_{11}-16-20 Y_{1 l}$ & .563 \\
\hline & & 1-5 Yil - 21 Yil Üstü & .999 \\
\hline & \multirow{2}{*}{ 11-15 Yil } & 6-10 Y1l-11-15 Y1l & .999 \\
\hline & & 6-10 Yil - 16-20 Yil & $.038 *$ \\
\hline & \multirow{2}{*}{ 16-20 Yil } & 6-10 Y1l - 21 Y1l Üstü & .635 \\
\hline & & $11-15 Y_{11}-16-20 Y_{11}$ & .999 \\
\hline & \multirow{2}{*}{21 Yil Üstü } & 11-15 Yil - 21 Yil Üstü & .999 \\
\hline & & 16-20 Y1l - 21 Yil Üstü & $.018^{*}$ \\
\hline
\end{tabular}

$* \mathrm{p}<, 05$ 
Tablo 5'te yer alan analiz sonuçları incelendiğinde öğretmenlerin ölçek alt boyutlarından aldıkları puanlar ile mesleki deneyimleri arasında rehber öğretmenler ve okul idarecileri ölçek alt boyutlarında anlamlı bir farklılık olduğu görülmektedir. Yapılan çoklu karşılaştırmalar sonucunda rehber öğretmenler alt boyutunda 6-10 Yil - 11-15 Yll $(\mathrm{p}=, 023)$ ve 11-15 Yil - 16-20 Yll $(\mathrm{p}=, 011)$; okul idarecileri alt boyutunda 6-10 Yıl - 16-20 Yil $(\mathrm{p}=, 038)$ ve 16-20 Yil - 21 Yil Üstü $(\mathrm{p}=, 018)$ arasinda anlamlı farklilı olduğu bulunmuştur. Öğretmenlerin branşlarına göre ANOVA test sonuçları Tablo 6'da görülmektedir.

Tablo 6. Ögretmenlerin Branşlarna Göre Ölçek. Alt Boyutlar Puanlarna İlişkin ANOV A Testi Sonuclar

\begin{tabular}{|c|c|c|c|c|c|c|c|}
\hline Alt Boyutlar & Varyans Kaynağı & $\begin{array}{c}\text { Kareler } \\
\text { Toplamı }\end{array}$ & sd & $\begin{array}{c}\text { Kareler } \\
\text { Ortalamas1 }\end{array}$ & $\mathbf{F}$ & $\mathrm{p}$ & $\eta 2$ \\
\hline \multirow{4}{*}{ Sınıf Öğretmenleri } & Gruplar Aras1 & 93.585 & 11 & 103.441 & .965 & .359 & .004 \\
\hline & Gruplar İçi & 22545.021 & 62 & 605.014 & & & \\
\hline & Toplam & 22638.606 & 73 & & & & \\
\hline & Gruplar Arası & 863.485 & 11 & 225.472 & 1,548 & .667 & .120 \\
\hline \multirow[t]{2}{*}{ Rehber Öğretmenler } & Gruplar İçi & 6358.401 & 62 & 199.502 & & & \\
\hline & Toplam & 7221.886 & 73 & & & & \\
\hline \multirow{3}{*}{ Uygulama } & Gruplar Arası & 53.811 & 11 & 44.585 & .969 & .155 & .004 \\
\hline & Gruplar İçi & 12566.931 & 62 & 61.136 & & & \\
\hline & Toplam & 12620.742 & 73 & & & & \\
\hline \multirow{3}{*}{$\begin{array}{l}\text { Mevzuat ve } \\
\text { Yönetmelikler }\end{array}$} & Gruplar Arası & 56.423 & 11 & 69.520 & .554 & .805 & .388 \\
\hline & Gruplar İçi & 89.075 & 62 & 62.287 & & & \\
\hline & Toplam & 145.498 & 73 & & & & \\
\hline \multirow{3}{*}{ Sivil Toplum Örgütleri } & Gruplar Aras1 & 695.630 & 11 & 135.846 & 2,736 & .999 & .085 \\
\hline & Gruplar İçi & 7447.586 & 62 & 84.036 & & & \\
\hline & Toplam & 8143.216 & 73 & & & & \\
\hline \multirow{3}{*}{$\begin{array}{l}\text { Rehberlik Araştırma } \\
\text { Merkezi }\end{array}$} & Gruplar Arası & 55.260 & 11 & 59,299 & .720 & .205 & .080 \\
\hline & Gruplar İçi & 633.541 & 62 & 50,112 & & & \\
\hline & Toplam & 688.801 & 73 & & & & \\
\hline \multirow{3}{*}{ Okul İdarecileri } & Gruplar Arası & 199.455 & 11 & 48.808 & .368 & .447 & .052 \\
\hline & Gruplar İçi & 3662.736 & 62 & 51.130 & & & \\
\hline & Toplam & 3862.191 & 73 & & & & \\
\hline \multirow{3}{*}{ Aileler } & Gruplar Arası & 87.114 & 11 & 13.552 & .801 & .688 & .090 \\
\hline & Gruplar İçi & 882.793 & 62 & 19.748 & & & \\
\hline & Toplam & 969.907 & 73 & & & & \\
\hline \multirow{3}{*}{ Fiziki Koşullar } & Gruplar Arası & 56.201 & 11 & 52.663 & .568 & .875 & .097 \\
\hline & Gruplar İçi & 525.141 & 62 & 76.487 & & & \\
\hline & Toplam & 581.342 & 73 & & & & \\
\hline \multirow{3}{*}{$\begin{array}{l}\text { Normal Gelişen } \\
\text { Çocuklar }\end{array}$} & Gruplar Aras1 & 78.578 & 11 & 24.559 & .445 & .237 & .101 \\
\hline & Gruplar İçi & 702.436 & 62 & 22.471 & & & \\
\hline & Toplam & 781.014 & 73 & & & & \\
\hline
\end{tabular}

$* \mathrm{p}<, 05$

Tablo 6'daki analiz sonuçları incelendiğinde branşlara göre ölçeğin sınıf öğretmenleri ( $\mathrm{t}=, 965$; $\mathrm{p}=, 359)$, rehber öğretmenler $(\mathrm{t}=1,548 ; \mathrm{p}=, 667)$, uygulama $(\mathrm{t}=, 969 ; \mathrm{p}=, 155)$, mevzuat ve yönetmelikler $(\mathrm{t}=, 554 ; \mathrm{p}=, 805)$, sivil toplum örgütleri $(\mathrm{t}=2,736 ; \mathrm{p}=, 999)$, rehberlik araştırma merkezi $(\mathrm{t}=, 720 ; \mathrm{p}=, 205)$, okul idarecileri $(\mathrm{t}=, 368 ; \mathrm{p}=, 447)$, aileler $(\mathrm{t}=, 801 ; \mathrm{p}=, 688)$, fiziki koşullar $(\mathrm{t}=, 568 ; \mathrm{p}=, 875)$ ve normal gelişen öğrenciler ( $\mathrm{t}=, 445 ; \mathrm{p}=, 237)$ alt boyutlarında istatistiksel açıdan anlamlı farklılık olmadığı bulunmuştur.

\section{Öğretmenlere göre kaynaştırma eğitiminde karşılaşllan sorunlara ilişkin bulgular}

$\mathrm{Bu}$ bölümde öğretmenlerin açık uçlu sorularla kaynaştırma eğitiminde karşılaştıkları sorunlar ve bekledikleri aileler desteklerin neler olduğuna ilişkin görüşleri alınmış, veriler analiz edilmiştir. Elde edilen bulgular aşağıda yer almaktadır. Öğretmenlere göre kaynaştırma öğrencilerinde karşılaşılan sorunlara ilişkin görüşler Tablo 7'de görülmektedir. 
Tablo 7. Öğretmenlerin Kaynaştırma Ögrrencilerinde Karşılaştıklan Sorunlar

\begin{tabular}{|c|c|c|}
\hline Öğretmenlerin kaynaştırma öğrencileri ile yaşadıkları sorunlar & Kişiler & $\mathbf{n}$ \\
\hline Öğrenciler yetersizlik durumunu suistimal etmektedir & $\mathrm{K} 1, \mathrm{~K} 2, \mathrm{~K} 21, \mathrm{~K} 27$ & 4 \\
\hline Davranış problemleri vardır & $\mathrm{K} 2, \mathrm{~K} 11, \mathrm{~K} 24$ & 3 \\
\hline Özbakım becerilerinde yetersizlik vardır & $\mathrm{K} 19, \mathrm{~K} 23$ & 2 \\
\hline Öğrencilerin düşük düzeydeki okullara yönlendirilmesi gerekir & $\mathrm{K} 4, \mathrm{~K} 25$ & 2 \\
\hline Öğretmenler kaynaştırma eğitimi konusunda yeterlidir & $\mathrm{K} 3$ & 1 \\
\hline Bazı sınıflarda kaynaştırma öğrenci sayısının yüksek olduğu görülmektedir & K5 & 1 \\
\hline Bazı öğrencilerin değerlendirilmesinde sıkıntılar bulunmaktadır & K6 & 1 \\
\hline Program yetiştirme kaygısı vardır & $\mathrm{K} 8$ & 1 \\
\hline Bu öğrencilerin uzman desteğine ihtiyacı vardır & K13 & 1 \\
\hline Ailelerin bilinçlendirilmesi gerekmektedir & K15 & 1 \\
\hline Özel eğitim destek odalarına ihtiyaç bulunmaktadır & K27 & 1 \\
\hline
\end{tabular}

Tablo 7. incelendiğinde; öğretmenlerin eğitim süreci içerisinde kaynaştırma öğrencileri ile yaşadıkları sorunlara ilişkin görüşleri incelendiğinde yetersizlik durumunu suiistimal etme (4), davranış problemleri (3), öz bakım becerilerinde yetersizlik (2), gibi sorunlarla karşı karşıya kaldıkları anlaşılmaktadır. Ayrıca öğrencilerin düşük düzeydeki okullara yönlendirildiği (2), sorunların öğretmen yetersizliğinden kaynaklanmadığı, öğretmenlerin kaynaştırma konusunda yeterli olduğu (1), bazı sınıflarda kaynaştırma öğrenci sayısının yüksek olduğu ve akran zorbalığı sorunlar1 olduğu (1), bazı öğrencilerin değerlendirilmesinde sıkıntılar bulunduğu (1), öğretmenlerde program yetiştirme kaygısının bulunduğu (1), öğrencilerin uzman desteğine ihtiyacının olduğu (1), ailelerin bilinçlendirilmesi gerektiği (1), özel eğitim destek odalarına ihtiyaç bulunduğu (1) görülmektedir. Öğretmenler, kaynaştırma öğrencileri ile çalışırken karşılaştıkları diğer sorunlardan ilk olarak özel gereksinimli öğrencilerin yetersizlik durumlarını suiistimal ettikleri vurgulanmıştır. Bir öğretmen;

"Ögrrenci, durumunun farkina varip bu durumu suiistimal etmesi ve diğer arkadaşlarma karşı koz olarak kullanması büÿ̈̈k bir sorun olusturmaktadir. Derslerde özel gereksinimli ögrencimiz ögretmen ve arkadaslar tarafindan ayrccallk istemektedir "(K1) bu durumda öğretmenimiz sınıf içerisinde sorunlar yaşadığını vurgulamıştır. Bir başka öğretmen da aynı konuya dikkat çekerek;

"Öğrenciler çalssmalara katılmamaktadır. Özel gereksinimli ögrencimiz. "nasıl olsa mezun oluruz düsüncesine bakimdir ve bu sebepten sorumluluk almaktan ve ödevlerini yapmaktan kaçınmaktadirlar" (E2) diyerek yaşanan sorunlara dikkat çekmiştir. Bir başka öğretmen ise;

"Baそ̨ kaynasstrma öğrencileri devamsız̨lk haklarmm diğer öğrencilerden fąla olduğunu bildikleri için bilerek devamsizllk yapmaktadirlar ve özel gereksinimli ögrenci kaynastorma öğrencisi nasil olsa kalmaz düs̈̈̈ncesiyle sinav sorularm okumak bile istememektedirler ve sadece sinav sorularndan birkaçın yapmaktadirlar" (K27) diyerek özel gereksinimli öğrencilerimizin yetersizlik durumlarını eğitim süreçlerinde suiistimal ettikleri vurgulanmıştır. Bir diğer problemin ise;

"Ergenlik döneminde ortaya çıan davranıs problemleri" (K11) diyerek özel gereksinimli öğrencilerin problemli davranışlarını kontrol altına almada sorun yaşadıklarına dikkat çekmişlerdir. Bir diğer öğretmen adayı ise;

“Ö₹ bakım becerileri, aileler tarafindan özel gereksinimli çocuklarna ögretilmeleri gerekmektedir. Özel gereksinimli ögrenciler, simf içerisinde ya da okul içerisinde planlanan sosyal etkinliklere daha fazla katulam sağlanmalar için desteklenmelidir" (K23). Bulgular genel olarak değerlendirildiğinde öğretmenlerin kaynaştırma eğitimi kapsamında ailelerden bekledikleri ek desteğin yanı sıra özel gereksinimli öğrencilerin problemli davranışları, öz bakım becerilerindeki yetersizlikler ve buna ek olarak bu öğrencilerin yetersizlik türlerini suiistimal etme durumu ile sorun yaşadıkları belirtilmiştir. Öğretmenlere son olarak bu konuda eklemek istedikleri konuların neler olduğu sorulmuş alınan cevaplar incelendiğinde aşağıdaki bulgulara ulaşılmıstır. Bir öğretmen kaynaştırma eğitimi yapan öğretmenlerin yeterli olduğunu, var olan olanaklara göre davrandıklarını belirtmiş;

"Öğretmenlerin yetersiz, olduğunu düsünmüyorum. İmkân dâhilinde hareket edebiliyoruz" (K3) demiştir. İki öğretmen ise kaynaştırma uygulamasının eğitim düzeyi yüksek Fen ve Anadolu Liselerinde de yapılması gerektiğini vurgulamıştır. Bu öğretmenlerden birisi,

"İyi liselerde de bu ögrencilere kontenjan ayrlması "(K4) gerektiğini, bir diğeri de;

"Normal eğitimde bu çocuklarn bulunmasin çok doğru ve adil bulmuyorum. Eğer doğru bir uygulamaysa fen lisesi ve diğer Anadolu liselerinde de bu çocuklarn olmasi gerekir. Bu tür alt kültürün geldiği okullarn eğgitimi normalde sılkintıl 
iken kaynaştırmalarla daha da sıkıntıl oluyor. Bazı simiflarda o kadar cok kaynaștırma var ki sını kaynaştırma ögrencilerin seviyesine düş̈̈yor "(K25) diyerek yaşanan olumsuzluğa dikkat çekmiştir. Bu sorunlardan başka bir öğretmen;

"Bir sınıfta eğitim gören dört veya altı kaynaștırma ögrencisine, akran zorbalı̆̆ım bertaraf ederek nasıl ulaşacağımı, bir yandan diğer ögrencilerin akademik seviyelerini nasıl yükeselteceğimi bilemediğim zamanlar oluyor "(K5) demektedir. Bir başka öğretmen ise;

"Rehabilitasyon merkęleri ve bilinçsiz aileler yüzünden herhangi bir zibinsel sıleıntısı olmasa dabi en azından ögrenme güçlü̆ü raporu alırı denilip çocuklarn etiketlenmesi problemi olduğunu düsünüyorum "(K6) demektedir. Programdan kaynaklı soruna dikkat çeken bir öğretmen de;

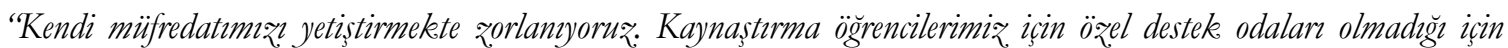
yeteri kadar vakit ayıramyoruz: Kaynasturma ögrencileri için özel alanlar olusturulursa onlara daha kolay destek olabiliriz. “(K8). Demektedir. Bir diğer öğretmen de kaynaştırma öğrencilerinin en az haftada bir kez özel eğitim uzmanı öğretmenden ders alması gerektiği konusuna dikkat çekmiş;

"Kaynaştırma ögrencilerinin en az, haftada bir gün kendi gibi kaynaștırma olan ögrencilerle bir araya gelip uz̧man ögretmenlerden eğitim almasi" (K13) gerektiğini vurgulamıştır. Ailelerin daha bilinçli olması gerektiğini belirten bir öğretmen de;

"Ailelerin bu konularda özellikle bilinçlendirilmesi gerekiyor. Çünkü veliler bu konuya sade para açsından yaklaşmakta. Onlar için önemli olan çocuklarna rapor alıp para gelmesi Buna bağh olarak gerekli kurumlarm, ögretmenler "olumsuz" rapor etmesine rağmen "olumlu rapor", "zihinsel engelli" vs. gibi rapor vermeleri. Bu konunun önüne geçilmesi gerekijor, sadece gerçekten gerekli olanlara rapor verilmesi lą̧m. Belirli dönemlerde okulları bilgilendirilmesi gerekiyor Tipk. sizin yaptığını gibi okullara uzman kişilerin gelerek eğitim vermesi gerekiyor. Kaynastırma ögrencilerine yönelik odalarm, destek ĕgitimine ait arac gereçlerin sağlanmasi gerekli. Calıs̆tı̆̆m okulda 100 ögrenci bulunmakta yaklaşı 35 ögrencimiz kaynaștırma, bu konuya çözüm bulunmasın talep ediyoruz. Simflarda raporu olan ve olmayan çok fazla davranıs problemi olan ögrencimiz var. Genel olarak ögretmen yetkileri artturlmal "(K15) demiştir. Son sirada özel sınıfların olması gerektiğine dikkat çeken bir öğretmen ise;

"Öz̨el ögrencilerin destek odalarında (sımflarnda) eğitimlerini yapması gereklidir. Bu bağlamda okullarda özel sınflar olmalıdır” (K27) diyerek görüşünü belirtmiştir. Öğretmenlerin kaynaştırma öğrencilerinde rastladıkları sorunlara ilişkin bulgular genel olarak değerlendirildiğinde öğrencilerin kendi durumlarını suiistimal ettikleri, davranış problemlerinin olduğu ve öz bakım becerilerinde yetersizliklerin bulunduğu anlaşılmaktadır. Ayrıca bazı öğretmenlerin kaynaştırma eğitimi konusunda yeterli olduklarını düşündükleri, bu öğrencilerin eğitim düzeyi yüksek okullara da yönlendirilmesi gerektiğini, bazı sınıflarda kaynaştırma öğrenci sayısının yüksek olması, akran zorbalığı gibi sorunlar olduğu, bazı öğrencilerin değerlendirilmesinde sıkıntılar olduğunu, program yetiştirme kaygısının kaynaştırma öğrencilerinin ihmaline neden olduğu ya da sınıfin düzeyini düşürdüğü, bu öğrencilerin uzman desteğine ihtiyacinın bulunduğu, özel eğitim destek odalarına ihtiyaç bulunduğu, ailelerin bilinçlendirilmesi gerektiği gibi sorunlar olduğu anlaşılmaktadır.

\section{Öğretmenlere Göre Ailelerden Beklentilere İlişkin Bulgular}

Öğretmenlere kaynaştırma öğrencilerinin başarılı olması için ailelerden beklentileri sorulmuş, öğretmenlerin bekledikleri desteklerin neler olduğuna ilişkin bulgular Tablo 8.de yer almaktadır.

Tablo 8. Öğretmenlerin Ailelerden Bekledikleri Destekler

\begin{tabular}{lcc}
\hline Öğretmenlere göre kaynaştırma eğitiminde aileden beklenen destekler & Kişiler & $\mathbf{n}$ \\
\hline Okul ziyaretlerinin yapılması /veli toplantılarına katılım sağlanmas1 & $\mathrm{K} 7, \mathrm{~K} 14, \mathrm{~K} 16, \mathrm{~K} 18, \mathrm{~K} 19$, & 12 \\
& $\mathrm{E} 20, \mathrm{~K} 22, \mathrm{~K} 23, \mathrm{~K} 25, \mathrm{~K} 26, \mathrm{~K} 27$ & \\
Özel gereksinimli çocuklarına daha fazla ilgi göstermeleri & $\mathrm{K} 1, \mathrm{~K} 6, \mathrm{~K} 8, \mathrm{~K} 12$, & 11 \\
& $\mathrm{~K} 13, \mathrm{~K} 17, \mathrm{~K} 18, \mathrm{E} 20, \mathrm{~K} 22, \mathrm{~K} 23, \mathrm{~K} 26$ & 4 \\
\hline
\end{tabular}


Tablo 8 incelendiğinde öğretmenlerin kaynaştırma eğitimi kapsamında eğitim verdikleri özel gereksinimli öğrencilerin ailelerinden bekledikleri desteklere ve bu öğrencilerle eğitim sürecinde yaşadıkları sorunlara ilişkin görüşleri incelendiğinde, ailelerin okul ziyaretlerini yapması ve veli toplantılarına katılım sağlaması (12), aileler tarafindan özel gereksinimli çocuklarına daha fazla ilgi göstermeleri (11), okulda yapılan çalışmaların ya da uygulamaların aileler tarafından evde desteklenmesi (4) gibi destekler bekledikleri anlaşılmaktadır. İlk sırada bir öğretmen;

"Ailelerin okul ve ögretmen ile işbirliğini güclendirmesi gerekmektedir. Veli toplantularma katullm sağlamalidrr. Ögretmen-veli ilişkisinin/iletisiminin sık olması” (K19) diyerek kaynaştırma eğitimi kapsamında okullara yerleştirilen öğrencilerinin eğitimi başarılı olması okul, öğretmen ve aile işbirliğine bağlı olduğu vurgulanmıştır. Bir diğer öğretmen okulda kaynaştırma öğrencileri ile çalışırken aile tarafından yeterli desteği alamadıklarını vurgulamıştır. Bir öğretmen;

"Ailenin kesinlikle evde destek vermesini, sme içerisinde neler yapuldiğ konusunda bilgilenmesini, okulda verilen eğitimin evde desteklenmesini ve sik sik okul ziyareti yapıp çocuklarmin durumunu ögretmenlerle görïsmesini istiyorum" (E20) demektedir. Bu eğitim sürecinin evde gerçekleşmemesi nedeniyle kaynaştırma eğitimi alan öğrencinin ve ders veren öğretmenin sorunlar yaşadığını vurgulamıştır. Bir başka öğretmen da aynı konuya dikkat çekerek;

"Okulda kaynastırma ögrencilerine ayurdĭgmı vakit kisıth olduğundan ailelerinde evde cocuklara yardımo olması gerektiüini düș̈̈nmekteyim. Böylece çocuklar da biraz daha ilerleme kaydedebiliriž" (K8) olduğunu belirtmiştir. Bir diğer problem aile ilgisizliğidir. Bir öğretmen;

"Aileleri ilgisiz olmasi, daha doğrusu cocuklar hakekinda bilgileri olamaması ve bu sebepten yeterli derecede yardimc olacak seviyede değillerdir"(K25) diyerek ailelerin çocukları konusundaki ilgisiz oluşlarına dikkat çekmiştir. Bulgular genel olarak değerlendirildiğinde öğretmenlerin ailelerden yeterli ve bilinçli düzeyde destek alamadıklarını, eğitim süreci içerisinde kazandırılan becerilerin ev ortamında aile tarafından desteklenmediği ve buna ek olarak ailelerin okul ile iletişimin çok az olduğu söylenebilir.

\section{Tartı̧̧ma, Sonuç ve Öneriler}

Öğretmenlerin cinsiyetine göre ölçeğin sınıf öğretmenleri, rehber öğretmenler, uygulama, mevzuat ve yönetmelikler, sivil toplum örgütleri, okul idarecileri, fiziki koşullar ve normal gelişen öğrenciler alt boyutlarında istatistiksel açıdan anlamlı farklılık olmadığı, rehberlik araştırma merkezi ve aileler alt boyutlarında anlamlı farklılık olduğu bulunmuştur. Bu sonucu sınıf öğretmenleri, rehber öğretmenler, uygulama, mevzuat ve yönetmelikler, sivil toplum örgütleri, okul idarecileri, fiziki koşullar ve normal gelişen öğrenciler boyutunda sonucu destekleyen Demir ve Açar'ın (2011) yaptığı bir çalışmada sınıf öğretmenlerinin kaynaştırma eğitimine yönelik görüşlerini incelemiş, cinsiyete göre kaynaştırma uygulamasında herhangi bir farklılık bulunmadığını ortaya koymuş olup sadece Rehberlik ve Araştırma Merkezi ve aileler boyutunda sonucu desteklenmemiştir. Bu sonuçları destekler nitelikte Camadan'ın (2012) araştırmasında BEP hazırlamaya ilişkin öz-yeterlik puanlarının cinsiyete göre anlamlı bir farklılık göstermediği ama kaynaştırma eğitimine yönelik erkek öğretmen adaylarının lehine anlamlı bir farklılık tespit edilmiştir. Tike' de (2007) yaptığı bir çalışmanın sonuçlarına göre, öğretmenlerin cinsiyetine göre BEP hazırlama sürecinde karşılaşılabilecek güçlükler konusunda aldıkları puanlar arasında anlamlı bir farklılık olmadığını bulmuştur. Yine Yaylacı ve Aksoy (2016) ve Bek, Gülveren ve Başer (2009) tarafindan yapılan çalışmalarda sırasıyla sosyal bilgiler öğretmenlerinin kaynaştırma eğitimi yeterliliklerinde ve kaynaştırmaya yönelik tutumlarında cinsiyet değişkenine göre anlamlı bir fark bulunmamıştır.

Bu çalışmada yaş grupları arasında sadece sivil toplum örgütleri alt boyutunda anlamlı bir farklılık olduğu görülmektedir. Bu farkın ise 20-29 Yaş ile 50-59 Yaş arasında ve 40-49 Yaş ile 50-59 Yaş arasında olduğu bulunmuştur. Bu sonucu desteklemeyen Soyyiğit (2013) yaptığı bir çalışmada sinıf öğretmenlerinin kaynaştırmaya yönelik tutumları incelenmiş, bu araştırmada yaş ile kaynaştırma uygulamaları arasında bir farklılık olmadığını belirlemiştir. Öğretmenlerin mesleki deneyimleri arasında rehber öğretmenler ve okul idarecileri ölçek alt boyutlarında anlamlı bir farklılık olduğu görülmektedir. Rehber öğretmenler alt boyutunda 6-10 Yil ile 11-15 Y1l ve 11-15 Yil ile 16-20 Y1l, okul idarecileri alt boyutunda 6-10 Yil ile 16-20 Yıl ve 16-20 Yıl ile 21 Yıl Üstü arasında anlamlı farklılık olduğu bulunmuştur. Öğretmenlerin branşlarına göre istatistiksel açıdan anlamlı farklılık olmadığı sonucuna ulaşılmıştır. Bu sonucu destekleyen Özcan (2020) tarafindan yapılan araştırmada okul öncesi öğretmenlerinin Kaynaştırma Eğitimine Yönelik Duygular, Tutumlar ve Kaygılar alt boyutunda mesleki deneyim süresi değişkenine göre anlamlı farka rastlanmamıştır. 
Öğretmenlerin kaynaştırma eğitimi alan öğrencilerinde rastladıkları problemler arasında öğrencilerin kendi durumlarını suiistimal ettikleri, davranış problemleri ve öz bakım becerilerinin yetersiz olduğu anlaşılmaktadır. Az da olsa kaynaştırma eğitimi konusunda kendilerinin yeterli olduğunu düşünen öğretmenler bulunduğu anlaşılmıştır. Bu sonucu desteklemeyen bir çalışmada öğretmenlerin büyük bir çoğunluğu kendilerini kaynaştırma eğitimi konusunda yeterli olmadıklarını belirtmişlerdir (Babaoğlan ve Yılmaz, 2010, s. 350). Elde edilen diğer sonuçlar arasında kaynaştırma öğrenci sayısının bazı sinıflarda yüksek olduğu, sınıflarda akran zorbalığına rastlandığı, bazı öğrencilerin değerlendirilmesinde sıkıntıların bulunduğu, yanlış değerlendirmelerin yapılabildiği, öğretmenlerin program yetiştirme kaygısının bulunduğu bu yüzden kaynaştırma öğrencilerinin ihmal edildiği ya da bu durumun sinıf düzeyini düşürdüğü, bu öğrenciler için özel eğitim destek odalarına ihtiyaç bulunduğu anlaşılmıştır. Benzer bir çalışmada öğretmenler, kaynaştırma eğitimi uygulamalarında öğrencilerle ilgili olarak destek eğitim odasının oluşturulmasını, uygulamaya yönelik olarak ise program yoğunluğun azaltılmasını istemektedir (Berkant, Atılgan, 2017). Çalışma sonuçları arasında kaynaştırma öğrencilerinin uzman desteğine, ailelerin bilinçlendirilmesi ve kaynaştırma öğrencilerinin her tür okula yönlendirilmesi gerektiği vb. sıralanabilir. Bu çalışma sonucunda öğretmenlerin kaynaştırma öğrencisine yönelik eğitim yöntemlerinin çok iyi olarak bilmedikleri anlaşılmıştır, bu sonucu destekleyen İzci'nin (2005) çalışmasında okullardaki kaynaştırma eğitimini hizmet içi eğitim görmüş öğretmenlerin verdiğini, birçok öğretmenin de özel eğitim konusunda herhangi bir sertifikasının olmadığını belirtmiştir. Elde edilen bulguyu destekleyen bir başka çalışmada ögretmenlerin kaynaştırma ve özel eğitim alanında bilgi ve deneyim eksiği, kaynaştırma eğitimine yeterli zaman ayıramadıkları belirtilmektedir (Ünal ve İflazoğlu Saban, 2014, s. 401). Bu çalışmanın sonuçlarına göre özel eğitim alanında öğretmen eksiklikleri, bulunmaktadır ve normal gelişim gösteren öğrencilerin kaynaştırma öğrencisine yönelik olumsuz tutum ve davranışlarının kaynaştırma eğitiminde problem yaşanmasına neden olduğu anlaşılmıştır. Kaynaştırma uygulamalarının daha etkili bir şekilde yapılabilmesi için bilgi ve donanım eksikliklerinin giderilmesi, öğretmen eğitimlerinin artırılması, normal gelişim gösteren çocukların olumsuz tutum ve davranışlarını iyileștirmeye yönelik planlamalar yapılması önerilmektedir. Öğretmen ve okulda bulunan diğer personelin kaynaştırma eğitimi öncesinde ve kaynaştırma eğitimi yapılırken engelli öğrenciler ve engellerine yönelik bilgi verilmesi onların bu eğitime hazırlaması gerektiği belirtilmiştir. $\mathrm{Bu}$ eğitimleri alan öğretmenler bu öğrencileri daha iyi anlayacak ve daha kolay kabullenebilecektir (Batu, 2000, s. 44). Bu sonucu destekleyen başka çalışmalarda da öğretmenlerin desteklenmesi gerektiği vurgulanmaktadır (Bilen, 2007; Evyapan, 2020; Varol, 2010). Örneğin Bilen' in (2007) yaptı̆̆ bir çalışmada sınıfta bulunan öğrenci sayısının fazla oluşu, aynı sınıfta 2 ya da 3 özel eğitim ihtiyacı bulunan öğrencinin bulunması gibi etkenlerin öğretmenlerin çalışmalarını zorlaştırdığı, öğretmenlerin birçoğunun kaynaştırma uygulaması ile ilgili herhangi bir eğitim almadığı, belirlenmiştir. Benzer bir çalışmada Varol (2010) tarafindan yapılmış, kaynaştırma öğretmenlerin yarısına yakınının kaynaştırma eğitimi konusunda bilgilerinin olmadığı anlaşılmışır. Öğretmenlerin ailelerden yeterli ve bilinçli düzeyde destek alamadıklarını, eğitim süreci içerisinde kazandırılan becerilerin ev ortamında aile tarafindan desteklenmediği ayrıca ailelerin okul ile iletişimin çok az olduğu anlaşılmaktadır. Öğretmen beklentileri arasında velilerin okulla daha fazla ilişki kurması, veli toplantılarına katılmasının önemli olduğu, ailelerin çocukları ile daha fazla ilgilenmesi ayrıca okulda yapılan etkinliklerin evde daha fazla desteklenmesi gerektiği yer almaktadır. Bu sonuca benzer Evyapan (2020, s. 87) tarafindan yapılan bir çalışmada okulöncesi öğretmenlerinin kaynaştırma eğitiminde uygulanan yöntem ve teknikleri bilme kullanabilme yeterliliği konusunda sınıfında 31 ve üstü öğrenci olan öğretmenlerin ortalama puanlarının sınıfında 0-10 öğrenci olan meslektaşlarına oranla daha yüksek olduğu, ölçme değerlendirme konusundaki yeterliliklerinde ise sınıfında 11-20 ve 31- üstü öğrenci olan öğretmenlerin ortalama puanlarının sınıfında 010 öğrenci olan meslektaşlarına oranla daha yüksek olduğu sonucuna ulaşılmıştır. Öğretmenlerin deneyimleri ve yeterlikleri arttıkça kaynaştırma eğitiminde başarılı olacağı söylenebilir.

\section{Öneriler}

Kaynaştırma öğrencisi velilerle okul arasında iyi bir iş birliğinin kurulmas1, velilerin eğitimle desteklenmesi önemlidir.

Velilerin okulla iş birliğine açı olmama nedenleri araştırılmalı, bu konuda yeni araştırmalar yapilmalidır.

Kaynaştırma öğrencilerinin aile tarafindan maddi olarak suiistimal edilmesi önlenmelidir. Öğretmenlere kaynaştırma eğitimine yönelik hizmet içi eğitimleri uygulama temelli olmalıdır.

Kaynaştırma öğrencilerin okullara adil ve eşit biçimde dağıtılarak izlenmesine önem verilmelidir. 


\section{Etik Beyan}

"Kaynastırma Uygulamalarmın Başarısın Etkileyen Etmenlerin Öğretmen Görïslerine Göre Değerlendirilmesi”" başlıklı çalışmanın yazım sürecinde bilimsel kurallara, etik ve alıntı kurallarına uyulmuş; toplanan veriler üzerinde herhangi bir tahrifat yapılmamış ve bu çalışma herhangi başka bir akademik yayın ortamına değerlendirme için gönderilmemiştir. Gerekli olan etik kurul izinleri Bartın Üniversitesi Sosyal ve Beşeri Bilimler Etik Kurulu'nun 28.08.2019 tarih ve 2019-170 kararı ile alınmıştır.

\section{Teşekkür}

Bu çalışma “Bartın Üniversitesi Bilimsel Araştırma Projesi 2019-SOS-A-002” olarak desteklenmiştir.

\section{Kaynakça}

Ahmetoğlu, E, Ünal, A. M. ve Ergin, D. Y. (2016). Kaynaştırma uygulamalarının başarısını etkileyen etmenler ölçeği’nin geliştirilmesi. Trakya Üniversitesi Ë̆itim Fakültesi Dergisi, 6(2), 167-175.

Akçin, N. (2017). Genel eğitim programları ve özel eğitim uygulamaları. İçinde A. Cavkaytar (Edt.). Özel eğitim. Ankara: Vize Yayıncilik.

Akman, B., Mercan Uzun, E. ve Yazıcı, D. N. (2018). Okul öncesi öğretmen ve öğretmen adaylarının kaynaştırmaya yönelik görüşlerinin karşılaştırılması. Mersin University Journal of the Faculty of Education, 14(1), 96-114.

Aküzüm, C. ve Altunhan, M. (2017). Okul öncesi öğretmenlerinin sınıf yönetim becerileri ile kaynaştırma eğitimi yeterliklerinin incelenmesi (Diyarbakır İli Örneği). Dicle Üniversitesi Ziya Gökalp Eğitim Fakültesi Dergisi, 31, 779802.

Ayvaz Öztürk, S. (2020). Kaynaşıtırma eğitimine ilişkin sosyal bilgiler alanında yapılan çalışmaların incelenmesi. Journal of Innovative Research in Social Studies, 3(1), 70-89.

Babaoğlan, E. ve Yılmaz, Ș. (2010). Sınıf öğretmenlerinin kaynaştırma eğitimindeki yeterlikleri. Kastamonu Eğitim Fakilltesi Dergisi, 18(2), 345-354.

Baki, A. ve Gökçek, T. (2012). Karma yöntem araşıtırmalarına genel bir bakış. Elektronik Sosyal Bilimler Dergisi, 11(42), $1-21$.

Batu, S. (2000). Kaynaştırma, Destek Hizmetler Ve Kaynaştırmaya Hazırlık Etkinlikleri. Özel Eğitim Dergisi, 2(24), 3545.

Batu, S. (2008). Kaynaştırma desteği sağlama. İçinde S. Eripek (Edt.). Öžl eğitim. Eskişehir: Anadolu Üniversitesi Açık Öğretim Fakültesi Yayınları.

Batu, S. ve Kırcaali-İftar, G. (2009). Kaynastırma (4. Baskı). Ankara: Kök Yayıncilı.

Bek, H., Gülveren, H. ve Başer, A. (2009). Sınıf öğretmeni adaylarının kaynaştırma eğitimine yönelik tutumlarının incelenmesi. Uşak Üniversitesi, Sosyal Bilimler Dergisi, 2(2), 160-168.

Berkant, H. ve Atılgan, G. (2017). Sınıf öğretmenlerinin kaynaştırma eğitimine yönelik yaşadıkları sorunlar veçözüm önerileri. Journal of Educational Reflections, 1(1), 13-25.

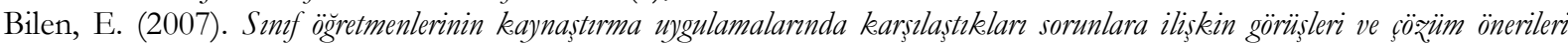
(Yüksek Lisans Tezi). Dokuz Eylül Üniversitesi, İzmir.

Bozarslan Malkoç, B. (2010). Eskişebir ilindeki özel anaokullarnda çalşsan eğiticilerin okul öncesi dönemde kaynastrtrmayla ilgili görïşlerinin incelenmesi (Yüksek Lisans Tezi). Anadolu Üniversitesi Eğitim Bilimleri Enstitüsü, Eskişshir.

Bulu, B. ve Hotaman, D. (2020). Kaynaşıtırma eğitimi: Gelişimi, yararları, karşılaşılan sorunlar ve fırsat eşitliği bağlamında programların incelenmesi. Uluslararast Sosyal Arastrmalar Dergisi, 13(71).

Camadan, F. (2012). Sınıf öğretmenleri ve sınıf öğretmeni adaylarının kaynaştırma eğitimine ve Bep hazırlamaya ilişkin öz-yeterliklerinin belirlenmesi. Elektronik Sosyal Bilimler Dergisi, 11(39), 128-138.

Demir, M. K. ve Açar, S. (2011). Kaynaştırma eğitimi konusunda tecrübeli sınıf öğretmenlerinin görüşleri. Kastamonu Ë̈itim Dergisi, 19(3), 719-732.

Evyapan, G. (2020). Okul öncesi ögretmenlerinin kaynaştrma eğitimine ilişkin öz-yeterlilik algz düreyleri ve bireysellestivilmiş eğitim programı bakkemdaki görï̌sleri (Yüksek Lisans Tezi). Balıkesir Üniversitesi Eğitim Bilimleri Enstitüsü, Balıkesir.

Gün Şahin, Z. ve Gürbüz, R. (2016). Kaynaştırma öğrencilerini eğiten ortaokul öğretmenlerinin yeterlikleri üzerine. Adiyaman Üniversitesi Eg̈itim Bilimleri Dergisi, 6(1), 138-160.

Işık, S. (2018). Okul öncesi ögretmenlerinin tam zamanl kaynasturma karar olan otizmli ögrencilerin eğitimine ilișkin görisslerinin incelenmesi (Yüksek Lisans Tezi). Toros Üniversitesi Eğitim Bilimleri Enstitüsü, Mersin

İzci, E. (2005). Sınıf öğretmeni adaylarının "özel eğitim” konusundaki yeterlikleri. Elektronik Sosyal Bilimler Dergisi, $4(14), 106-114$

Karasar, N. (2011). Bilimsel Araștırma Yöntemi (22. Baskı). Ankara: Nobel Yayın Dağıtım.

Loreman, T., Deppeler, J. ve Harvey, D. (2005). Inclusive education: A practical guide to supporting diversity in the classroom. New Jersey: Routledge Falmer.

MEB (2012). Özel Ë̈itim Hizmetleri Yönetmeliği. Resmi Gazete, Yayım Tarihi: 21 Temmuz 2012, Sayıss: 28360Milli Eğitim Bakanlı̆̆ı Özel Eğitim Kurumları Yönetmeliği (2006, 31 Mayı). Resmi Gazete (Sayl: 26184). Erişim adresi: https://orgm.meb.gov.tr/alt_sayfalar/mevzuat/Ozel_Egitim_Hizmetleri_Yonetmeligi_son.pdf

Nazif Toy, S. ve Duru, S. (2016). Sınıf öğretmenlerinin öğretmen öz yeterlikleri ile kaynaştırma eğitimine ilişkin yeterlik inançlarının karşılaştırılması. Ege Ë̆itim Dergisi, 17(1), 146- 173. 
Orel, A., Zerey. Z. ve Töret, G. (2004). Sınıf öğretmeni adaylarının kaynaştırmaya yönelik tutumlarının incelenmesi. Ankara Üniversitesi Ë̆itim Bilimleri Fakültesi Özel Eğitim Dergisi, 5, 23-33.

Özcan, İ. (2020). Okul öncesi ögretmenlerinin kaynasstırma eğitimine yönelik duygular tutumlar ve kaygzlar ile kaynaștırma uygulamalarndaki ögretmen yeterlilikleri arasindaki ilişkinin incelenmesi (Yüksek Lisans Tezi). Pamukkale Üniversitesi Ĕ̆itim Bilimleri Enstitüsü, Denizli.

Öztürk, H., Ballığlu, G. ve Şen, G. (2014). Öğretmen adaylarının özel eğitimde kaynaştırma uygulamalarına yönelik tutumlarının incelenmesi. Muğla Eğitim Fakültesi Dergisi, 1(1), 1-13.

Sadioğlu, Ö., Bilgin, A., Batu, S. ve Oksal, A. (2013). Sınıf öğretmenlerinin kaynaştırmaya ilişkin sorunları, beklentileri ve önerileri. Kuram ve Uygulamada Ĕ̈itim Bilimleri, 13(3),1743-1765.

Sanır, H. (2009). Kaynastırma eğitimine devam eden ögrencilerin akademik ögrenme ile ilgili karşılasstıklar sorunlarn ögretmen ve aile görüsleri açısından değerlendirilmesi (Yüksek Lisans Tezi). Selçuk Üniversitesi Eğitim Bilimleri Enstitüsü, Konya

Sart, H., Ala, H., Yazlık, Ö. ve Yılmaz, F. (2004). Türkiye kaynaştırma eğitiminde nerede? Eğitimciye öneriler. XIII. Ulusal Eğitim Bilimleri Kurultayı'nda Sunulmuş Rapor.

Soyyiğit, T. (2013). Simf ögretmenlerinin değer tercibleriyle kaynaştırmaya yönelik tutumlar arasındaki ilişkinin incelenmesi (Istanbul Ili, Pendik ilģesi örneği) (Yüksek Lisans Tezi). Yeditepe Üniversitesi Eğitim Bilimleri Enstitüsü, İstanbul.

Sucuoğlu, B. ve Akalın, S. (2010). Kaynaştırma sınıflarına alternatif bir bakış: Çevresel davranışsal değerlendirme ile öğretimsel özelliklerin incelenmesi. Ankara Üniversitesi Eğitim Bilimleri Fakültesi Özel Eğitim Dergisi, 11(1), 19-37.

Şahbaz, Ü. ve Kalay, G. (2010). Okulöncesi eğitimi öğretmen adaylarının kaynaştırmaya ilişkin görüşlerinin belirlenmesi. Mehmet Akif Ersoy Üniversitesi Eğitim Fakültesi Dergisi, 9, 116-135.

Şekercioğlu, B. (2010). İlkögretim II. kademe brans ögretmenlerinin kaynaştırma uygulamalarnda karşılaştıklar sorunlar ile ilgili görüsleri (Yüksek Lisans Tezi). Gazi Üniversitesi Eğitim Bilimleri Enstitüsü, Ankara,.

Tike, L. (2007). Sinf ögretmenleri, rehber ögretmenler ve rehberlik araștırma merkę̧i çalısanlarmm bireyselleștirilmis eğitim program baz̨ırlama sürecine ilişkin tutumlar ve bu süreçte karşılasstıklar güclüklerin belirlenmesi (Yüksek Lisans Tezi). Ankara Üniversitesi Eğitim Bilimleri Enstitüsü, Ankara.

Uysal, A. (2004). Kaynaştırma uygulaması yapan öğretmenlerin kaynaştırmaya ilişkin görüşleri. İçinde A. Konrot (Edt:). Özel Eğitimden Yansimalar - 13. Ulusal Özel Eğitim Kongresi Bildirileri (ss. 121-135). Ankara: Kök Yayınc1lık.

Ünal, F. ve İflazoğu Saban, A. (2014). Kaynaştırma uygulamasının yapıldığı sinıflarda, öğretmenlerin kaynaştırmaya yönelik tutumları. C..Ü. Sosyal Bilimler Enstitüsü Dergisi, 23(1), 388-405.

Varol, Ç. (2010). İlkögretim okullarndaki kaynaștırma uygulamalarmm değerlendirilmesi. Millî Eğitim Bakanlı̆̆1, Eğitimi Araştırma ve Geliştirme Dairesi Başkanlığı (EARGED). Ankara: MEB Kaynak Kitaplar Dizisi.

Yaylacı, Z. ve Aksoy, B. (2016). Sosyal bilgiler öğretmenlerinin kaynaştırma eğitimindeki yeterlilikleri. Uluslararası Türk Eğitim Bilimleri Dergisi, 2016(6), 19-40.

\section{EXTENDED ABSTRACT}

The purpose of this study is to reveal the success of inclusive education towards teachers who work in the schools which have inclusive education in Bartın province and to identify the problems and propose solutions related to inclusive education. Teachers' opinions on factors that affect the success of inclusive education practices were compared according to age, gender, professional experience, and branches to fulfill the purpose of the study. Besides, in terms of teachers' views, open-ended questions about what kind of problems encountered in inclusive education and what support teachers expect from families were presented. The study is designed as mixed-method research in which quantitative and qualitative methods are used together. The research was analyzed by using SPSS program, and t-test, ANOVA and post-hoc (LSD test) tests have been applied to obtain the research findings. To specify the study group of the research, seven schools with the highest number of students from the schools that receive full-time inclusive education from Bartın Counseling Research Center were determined. In this study, "The Scale of the Factors Affecting the Success of Inclusion" developed by Ahmetoğlu, Ünal, and Ergin (2016) has been applied to teachers. According to the research findings, there was a significant difference between the Counseling and Research Center and sub-dimensions of families, and subdimension of the non-governmental organizations by age groups. It was determined that while there was a significant difference between the dimensions of guidance counselors and principals in terms of professional experiences, there was no significant difference in branches. Findings also showed that teachers did not receive sufficient and conscious support from families, that the skills gained during the education process were not supported by families in their home, and families had inadequate communication with school staff. The teachers' expectations were regarding parental involvement, such as the importance of participation in school meetings, supporting school activities at home, and generally being more interested in their children. As a result of the research, it is consistent with the literature that there was no significant difference in the sub-dimensions of classroom teachers, guidance counselors, practices, legislation and regulations, non-governmental organizations, principals, physical conditions, and typically-developing students. In this study, there was the only difference in sub-dimension of the non- 
governmental organizations by age groups. The significant difference was found in age groups between 20-29, 50-59, 40-49, 50-59. Among the professional experiences of teachers, there is a significant difference between the sub-dimensions of the scale of guidance counselors and principals. It was found that there was a substantial difference between 6-10 years - 11-15 years and 11-15 years - 16-20 years in sub-dimension of guidance counselors, 6-10 years - 16-20 years and 16-20 years - over 21 years in subdimension of principals. It was concluded that there was no statistically significant difference between teachers by their branches. Among the problems faced by teachers in inclusive education students, it is understood that students who take inclusive education abuse of their special needs, they have behavioral issues and their self-care skills are inadequate. It was also revealed that few teachers think that they are sufficient in inclusive education. Researchers determined in this study that the majority of teachers find themselves insufficient in inclusive education. It turned out from research findings that the number of mainstreaming students was high in some classes, peer bullying was encountered in classrooms, there were difficulties in the assessment of some students, assessment errors are possible, teachers are concerned about following the curriculum, therefore students in inclusive education were neglected, or this situation decreased the class levels, the expert support, and special-needs Resource Rooms are needed for students in inclusive education, parents' awareness should be increased and students in inclusive education should be directed to all types of schools. As a result of this research, it has been understood that teachers do not adequately know the teaching methods towards the students in inclusive education. It has been noted that teachers have insufficient qualifications in terms of special education and the negative attitudes and behaviors of typically-developing students towards the students in inclusive education cause problems in inclusive education. It is recommended that to make inclusive education practices more adequate knowledge and equipment deficiencies would be eliminated, training for teachers would be increased, making plans to improve typically-developing students' negative attitudes. It has been stated that there is a necessity that teachers and school staff should be informed information about disabled students and their disabilities before and during inclusive education, they should be prepared for inclusive education. It has been understood that teachers have not received sufficient and conscious support from families, the skills acquired during the education process have not been supported by the family in the home, and there is no effective communication between families and the school. The teachers' expectations are regarding parental involvement, such as the importance of participation in school meetings, supporting school activities at home, and generally being more interested in their children. It can be said that teachers will be successful in inclusive education as their professional experiences and competencies in special education improve. It has been revealed that it is crucial to collaborate with school and family in the sense of inclusive education. In this context, providing training to increase the collaboration between parents who have students in inclusive education and to increase the awareness of parents, investigating the reasons for parents' avoidance of cooperation, providing in-service training for inclusive education to teachers in practice, and to distribute students in inclusive education equally into schools/classes can be counted among the suggestions for practitioners. 